\author{
Самофратова B.A. \\ кандидат економічних наук, доцент \\ E-mail: vica_samofatova@mail.ru \\ Кулакова I.C. \\ магістрант \\ кафедра економіки промисловості \\ Одеська національна академія харчових технологій \\ вул. Канатна, 112, м. Одеса, Україна, 65039 \\ E-mail: rsaltevskiy@mail.ua
}

\title{
АМОРТИЗАЦЙНА ПОЛІТИКА: ТЕОРЕТИЧНІ ЗАСАДИ ТА ЇЇ РОЛЬ В ПІДВИЩЕННІ ЕФЕКТИВНОСТІ ДІЯЛЬНОСТІ ПІДПРИЄМСТВ
}

У статті проводиться критичний аналіз відтворення основного капіталу та сучасної амортизаційної політики українських підприємств і наводяться пропозиції щодо її покращення, розглядаються основні аспекти сучасної амортизаційної політики в контексті положень Податкового кодексу України. Виділено основні принципи проведення політики на всіх рівнях господарювання.

Ключові слова: амортизація, відтворення, основні засоби, ефективність, інвестиції.

Постановка проблеми та їі зв'язок з важливими науковими i практичними завданнями. Відсутність виваженої державної амортизаційної політики в Україні в період становлення ринкових відносин призвела до порушення механізму відтворення основних засобів на підприємствах, наслідком якого виявилася невідповідність амортизаційних відрахувань фінансовим потребам в оновленні технічної бази. Лібералізація економічних відносин в Україні позначилася втратою належного контролю 3 боку держави за цільовим використанням амортизаційних коштів. Із джерела фінансування реальних інвестиційних проектів вони на більшості підприємств перетворилися у джерело поповнення оборотних коштів.

Здійснення економічних реформ в Україні, таким чином, має бути спрямоване на трансформацію вітчизняного господарського механізму. Впровадження науково-технічних досягнень у виробництво, вирішення багатьох соціально-економічних проблем $\epsilon$ можливим лише за умови здійснення ефективної інвестиційної політики, складовою якої є амортизаційна політика. Саме амортизаційна політика як діючий інструмент державного регулювання процесу відтворення основних засобів повинна створювати сприятливі умови для стимулювання процесу оновлення основних засобів як технічної бази виробництва, сприяти зміцненню фінансової бази підприємств, їх інноваційній орієнтації і бути інструментом поєднання підприємницьких і загальнодержавних економічних інтересів.
Аналіз останніх публікацій 3 проблеми. Значний внесок у розробку теоретико-методологічних основ амортизації та відтворення основних засобів внесли: Н.Д. Бабяк, Л.В. Городянська, Н.О. Дугієнко, П.А. Орлов, В.І. Рошило, А.В. Хотомлянський та ін.

Формулювання цілей дослідження. Метою дослідження $є$ аналіз організаційно-економічних механізмів формування і реалізації амортизаційної політики на основі визначення сутності амортизації як джерела фінансування відтворення основних засобів, удосконалювання методів нарахування, нагромадження й використання амортизаційних відрахувань, а також розробка пропозицій щодо підвищення ефективності амортизаційної політики на підприємствах України.

Виклад основних результатів і їх обгрунтування. Економічна практика останніх років довела, що ефективність розвитку будь-якого регіону або країни в цілому залежить, переважним чином, від рівня i характеру інвестиційної діяльності. Без успішного іiї здійснення неможливо забезпечити економічне зростання, приріст соціального ефекту, інституціональну збалансованість. Таким чином, сьогодні Україна стоїть перед необхідністю активізації інвестиційної діяльності, модернізації і реконструкції діючих суб'єктів господарювання, а також створення конкурентоспроможних нових підприємств. В умовах стрімкого розвитку нових технологій саме інвестиції є провідним засобом забезпечення прогресивних зрушень в економіці, поліпшення 
якісних показників діяльності на мікро- і макрорівнях [2]. Чим масштабніші обсяги і вища ефективність інвестицій, тим швидше відбувається відтворювальний процес, здійснюються позитивні ринкові перетворення. Але для сталого розвитку економіки потрібне не просто залучення інвестицій, а побудова ефективного організаційно-економічного механізму постійного обороту капіталу, що відшкодовується і відновлюється на високому науково-технічному рівні. Амортизаційна політика, таким чином, представляючи собою частину інвестиційної політики, має створювати умови для обороту основного капіталу, виконуючи при цьому на макрорівні функції по формуванню частини фондів державних видатків через вплив на фінансові результати суб'єктів господарювання, а отже, на величину податку на прибуток. Протиріччя, яке виникає при цьому, є об'єктом дискусій на всіх рівнях управління і може бути лише пом'якшеним через узгодження інтересів держави та суб' єктів господарювання [4].

Аналіз проблем відтворення основного капіталу і амортизаційної політики в Україні свідчить про те, що на сьогоднішній день оновлення основного капіталу виявилося вразливою сферою через відсутність стимулів до його відновлення та недосконалість економічного механізму амортизації [1].

В Україні через високу конфліктність інтересів держави та підприємств амортизаційну політику можна розглядати окремо на макро- i мікрорівні. На макрорівні взагалі відсутні механізми впливу на ефективність інвестиційної політики через амортизаційну політику [4]. Таким чином, остання зводиться до максимізації надходжень від податку на прибуток, при розрахунку якого використовуються амортизаційні відрахування. При цьому в інших розвинених країнах розроблені на державному рівні та впроваджені раціональні моделі амортизації основного капіталу, які заохочують підприємців до збільшення амортизаційних відрахувань. У такий спосіб формується додатковий приплив капітальних ресурсів не на разовій, а на постійній основі, за рахунок відкриття внутрішніх каналів інвестиційної підтримки виробництва.

Нарощуванню потенціалу підприємств перешкоджають не тільки неузгодженість інтересів на макро- та мікрорівні, але й загальне скрутне економічне становище суб'єктів господарювання та економіки в цілому. На рисунку 1 представлена динаміка інвестицій в основні засоби протягом останніх років.

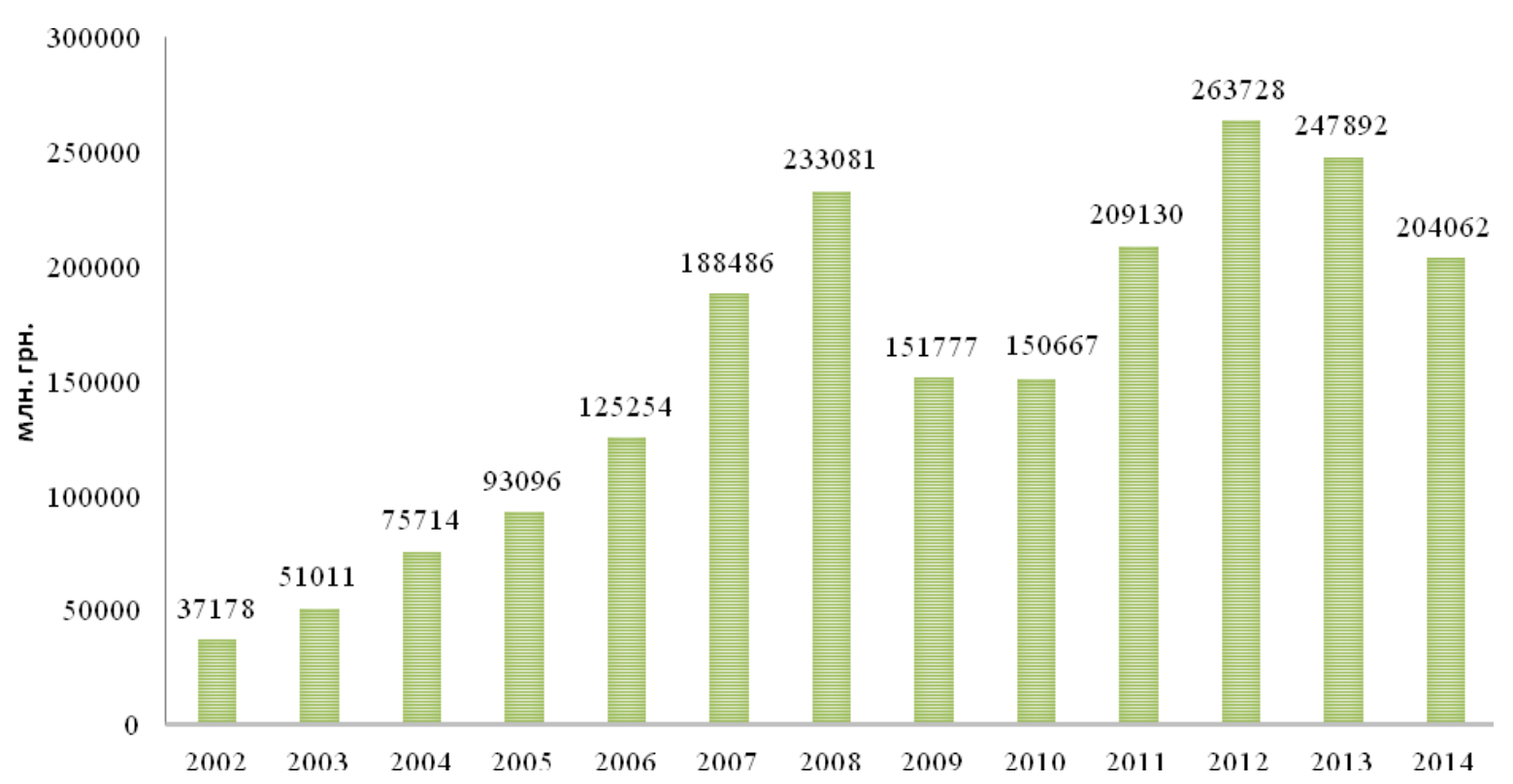

Рис. 1. Динаміка інвестицій в основний капітал в Україні [10]

Таким чином, протягом 2002-2008 років прослідковується позитивна тенденція до активізації інвестиційної діяльності підприємств, що говорить про нарощування суб'єктами господарювання свого потужнісного, виробничого та техніко-технологічного потенціалу. Світова фінансова криза 2008 року призвела до стрімкого зниження інвестиційної актив- ності підприємств. В 2010 році почалося відновлення позитивної тенденції, однак в 2013 році через початок ATO, внутрішню політичну та економічну кризу обсяг інвестицій в основний капітал почався стрімко скорочуватися.

На сьогоднішній день $є$ необхідність в оновленні основного капіталу на новій технічній основі і 
на базі прогресивних технологій. Але при цьому необхідно розв'язати дві проблеми. Перша полягає в тому, що підприємства повільно змінюють номенклатуру устаткування, яке випускається, не забезпечують потреби у передовій техніці. Друга - у відсутності достатнього фінансування, бо аналіз інноваційної активності промислових підприємств показав, що серед факторів, які гальмують інноваційну діяльність першу позицію (89\% обстежених) займає відсутність фінансування [3]. Тому за ринкових відносин важливого значення набуває вибір оптимальної структури джерел фінансування відтворення і оновлення основного капіталу.

Саме власні джерела визначають інвестиційний потенціал підприємств. Причому, в структурі власних джерел, найбільша частка припадає на амортизаційні відрахування, оскільки сьогодні, зважаючи на фінансовий стан підприємств України, не можна робити акцент на прибуток як основне джерело техніко-технологічного розвитку. Це пов'язано з тим, що у 2014 році частка збиткових підприємств складала $55,1 \%$. Спираючись на досвід розвинених країн і прогнози експертів, можна стверджувати, що роль нерозподіленої частини прибутку в джерелах фінансування буде зростати, але не досить суттєво.

Отже, в процесі самофінансування технікотехнологічного розвитку амортизаційним відрахуванням належить провідна роль [5]. В умовах триваючих трансформаційних процесів в економіці України підвищується значення амортизації як джерела відтворення основного капіталу, що обумовлено впливом науково технічного прогресу, змінами у формуванні структури капітальних вкладень, прискоренням морального спрацювання, переглядом норм амортизаційних відрахувань у бік збільшення, розширенням прав підприємств у використанні методів нарахування амортизації та відповідних сум амортизаційних відрахувань.

На жаль, на сьогоднішній день законодавча i нормативно-методична база, яка регулює систему амортизації не орієнтується на довгострокову концепцію реформування амортизаційної політики і не підготовлена для практичного використання. Вона більше відпрацьована з позиції виконання фіскальних функцій, а не 3 позиції відтворення основного капіталу. Тому амортизаційна політика сьогодні не сприяє, а протидіє накопиченню реноваційних ресурсів і не створює на підприємствах фінансову базу для відтворення капіталу як основу досягнення позитивної економічної динаміки і економічного росту. За рахунок амортизаційних відрахувань в Україні не відбувається навіть просте відтворення основного капіталу, а тим паче його реконструкція й переоснащення. Діюча амортизаційна політика не дає змогу відтворювати основні засоби виробництва за рахунок амортизаційних відрахувань [7, 8].

Треба однак відзначити, що останнім часом нашою державою здійснюються спроби підвищити ефективність стимулюючої функції амортизаційної політики, що відображається в орієнтації на міжнародні стандарти як у напрямку економічно доцільних строків корисного використання основних засобів, так i застосуванні нових ефективних механізмів нарахування амортизаційних відрахувань. Так, Податковим кодексом України значно розширені можливості підприємств по застосуванню прискореної амортизації, що створює умови максимально ефективного процесу відтворення основних фондів. Значно збільшена кількість класифікаційних груп 3 відповідними граничними строками експлуатації, що говорить про більш адекватне 3 погляду відтворювального процесу нарахування амортизації [9].

Протягом ряду останніх років для економіки України був характерним спад ділової активності. Ці обставини змушували підприємства використовувати амортизаційні відрахування для фінансування поповнення оборотних коштів, що привело до значного старіння основних засобів. В результаті на сьогоднішній день амортизаційні відрахування не можуть забезпечити навіть простого відтворення цих активів.

Проведений аналіз дозволив виділити основні засади підвищення ефективності амортизаційної політики в трансформаційній економіці України:

- амортизаційна політика трансформаційного періоду повинна включати механізми фіскального та стимулюючого характеру;

- ввести відповідно до стратегії пріоритетів структурної та науково-технологічної політики пільги з податку на прибуток, що спрямовується на реінвестування;

- розробити і впровадити систему нормативно-правових актів для здійснення державного контролю за виконанням законодавчих положень амортизаційної політики та пов' язаних 3 цим елементів податкового законодавства.

Висновки і перспективи подальших досліджень. Резюмуючи вищевикладений матеріал, можна відзначити наступне:

- в умовах діючого порядку нарахування амортизаційних відрахувань, амортизація не є відображенням зносу основних засобів, а функціонує лише як засіб розподілу авансованих в основні засоби коштів протягом цілого ряду калькуляційних періодів. 
- як складова інвестиційної політики амортизаційна політика як на мікро-, так і на макрорівні має будуватися на засадах взаємної узгодженості інтересів держави та підприємств.

\title{
Література
}

1. Бабяк Н. Д. Вплив амортизаційних відрахувань на результати фінансово-господарської діяльності підприємств / Н.Д. Бабяк // Фінанси України. - 2001. - № 11. - С. 34-40.

2. Городянська Л. В. Відтворення основних засобів на підприємствах України: теорія і практика обліку та аналізу : Монографія. / Л. В. Городянська. - К. : КНЕУ, 2008. - 224 с.

3. Дугієнко Н. О. Роль внутрішніх джерел інвестування у виробництво в сучасних умовах // Економіка: проблеми теорії та практики. Збірник наукових праць. Випуск 154 (2 т.). - Дніпропетровськ : ДНУ, 2002. - С. 131-137.

4. Орлов П. А. Амортизаційна політика як інструмент активізації інвестиційної та інноваційної діяльності підприємств / П. А. Орлов, С. П. Орлов // Інновації: проблеми науки і практики : Монографія. - Х. : ВД «НЖЕК», 2006. - C. 317-335.

5. Осипов П. В. Інтегральний виробничий потенціал харчової промисловості / П. В. Осипов. - Одеса, 2004. $-286 \mathrm{c}$.

6. Рошило В. І. Особливості амортизації як фінансової категорії економіки перехідного типу / В. І. Рошило // Економіка: проблеми теорії та практики : Зб. наук. пр. Дніпропетровського національного ун-ту. Дніпропетровськ : ДНУ, 2002. - Вип. 121. - С. 161-166.

7. Хотомлянський А. В. Амортизаційний фонд як джерело відтворення основних засобів А. В. Хотомлянський // Економіка України, № 3. - 2004. - С. 33-38.

8. Положення (стандарт) бухгалтерського обліку №7 «Основні засоби», затверджене наказом Міністерства фінансів України від 18.10.1999 р. № 242, зі змінами й доповненнями

9. Податковий кодекс України від 03.12.2010 р. зі змінами й доповненнями.

10. Державний комітет статистики України [Електронний ресурс]. - Режим доступу : http://www.ukrstat.gov.ua.

\author{
Самофратова B.A. \\ кандидат экономических наук, доцент \\ E-mail: vica_samofatova@mail.ru \\ Кулакова И.С. \\ магистрант \\ кафедра экономики промышленности \\ Одесская национальная академия пищевых технологий \\ ул. Канатная, 112, г. Одесса, Украина, 65039 \\ E-mail: rsaltevskiy@mail.ua
}

\section{АМОРТИЗАЦИОННАЯ ПОЛИТИКА: ТЕОРЕТИЧЕСКИЕ ОСНОВЫ И ЕЕ РОЛЬ В ПОВЫШЕНИИ ЭФФЕКТИВНОСТИ ДЕЯТЕЛЬНОСТИ ПРЕДПРИЯТИЙ}

В статье проводится критический анализ воспроизводства основного капитала и современной амортизационной политики украинских предприятий и приводятся предложения по ее улучшению, рассматриваются основные аспекты современной амортизационной политики в контексте положений Налогового кодекса Украины. 
Определено, что одной из важнейших сфер экономических отношений в государстве является процесс воспроизводства производственного потенциала субъектов хозяйствования. На пути построения рыночных отношений в нашей стране, наряду с формированием рынка капитала, целенаправленного регулирования требует процесс воспроизводства основных фондов, поскольку они во многом определяют эффективность общественного производства, темпы внедрения научно-технического прогресса, роста национального дохода и благосостояния населения.

Совершенствование амортизационной политики - одно из важнейших направлений деятельности государства в области реформирования экономики, способствует сохранению, техническому перевооружению и дальнейшему развитию производства, успешной реализации научноисследовательского потенциала предприятий. Несоответствие амортизационной политики реальным процессам, протекающим в экономике, приводит к деформациям в обороте основного капитала, замедлению процесса введения новой и вывода из эксплуатации физически и морально устаревшей техники.

Современная амортизационная политика государства характеризуется наличием тенденций либерализации. Оптимизация амортизационной политики является одним из элементов реформирования предприятия. Амортизационные отчисления формируют доходную часть бюджета амортизации, которая должна быть сбалансирована с его расходной частью, обусловленной потребностью в инвестициях.

Возможность оптимизации амортизационных сумм позволяет предприятию целенаправленно влиять на финансовые результаты производства и хозяйственную стабильность предприятия. При реализации мероприятий, направленных на оптимизацию амортизационных механизмов, функционирующих на предприятии, необходимо учитывать конкретные условия осуществления хозяйственной деятельности, которые фрормируются под влиянием фракторов микро- и макроэкономической среды, и опираться на анализ действующих норм.

Ключевые слова: амортизация, воспроизводство, основные средства, эффективность, инвестиции.

\author{
Samofatova V.A. \\ Ph.D. in Economics, Associate Professor \\ E-mail: vica_samofatova@mail.ru \\ Külakova I.S. \\ Undergraduate \\ Department of Industrial Economics \\ Odessa National Academy of Food Technologies \\ Kanatna str., 112, Odessa, Ukraine, 65039 \\ E-mail:rsaltevskiy@mail.ua
}

\title{
DEPRECIATION POLICY: THEORETICAL PRINCIPLES AND ITS ROLE IN IMPROVING THE EFFICIENCY OF ENTERPRISES
}

In the article determined that a major area of economic relations in the state is the reproduction of productive capacity of business entities. On the way to build a market economy in our country, along with the formation of capital market targeted regulation requires the reproduction of fixed assets, as they largely determine the effectiveness of social production, the pace of scientific-technical progress, the growth in national income and welfare.

Improving depreciation policy - one of the most important activities of the state in economic reform, promoting preservation, modernization and further development of production, the successful implementation of the research potential of enterprises. Inconsistency depreciation policy the real processes occurring in the economy, leading to strains in circulation of capital, slowing the process of introducing new and decommissioning and physically obsolete equipment. 
Modern depreciation policy states characterized by liberalization trends.

Optimization depreciation policy is one element of reforming the company. Depreciation forming a profitable part of the budget depreciation should be balanced with its expenditure part, determined by the need for investment.

The ability to optimize the amounts of depreciation allows the company to deliberately affect the financial results of production and economic stability of the company.

With the implementation of measures aimed at optimizing depreciation mechanisms that operate the company must take into account the specific conditions of economic activity that are influenced by factors micro- and macroeconomic environment, and based on the analysis of existing rules.

Keywords: depreciation, reproduce, fixed assets, efficiency, investments.

\section{References}

1. Babiak N.D. (2001). Vplyv amortyzatsiinykh vidrakhuvan na rezultaty finansovo-hospodarskoi diialnosti pidpryiemstv. Finansy Ukrainy. № 11, 34-40.

2. Horodianska L.V. (2008). Vidtvorennia osnovnykh zasobiv na pidpryiemstvakh Ukrainy: teoriia i praktyka obliku ta analizu: Monohrafiia. K.: KNEU, 224.

3. Duhiienko N.O. (2002). Rol vnutrishnikh dzherel investuvannia u vyrobnytstvo v suchasnykh umovakh. Ekonomika: problemy teorii ta praktyky. Zbirnyk naukovykh prats. Vypusk 154 (vol.2). Dnipropetrovsk: DNU, 131137.

4. Orlov P.A., Orlov S.P. (2006). Amortyzatsiina polityka yak instrument aktyvizatsii investytsiinoi ta innovatsiinoi diialnosti pidpryiemstv. Innovatsii: problemy nauky i praktyky: Monohrafiia, Kh.: VD «INZhEK», 317335 .

5. Osypov P.V. (2004). Intehralnyi vyrobnychyi potentsial kharchovoi promyslovosti. Odesa, 286.

6. Roshylo V.I. (2002). Osoblyvosti amortyzatsii yak finansovoi katehorii ekonomiky perekhidnoho typu. Ekonomika: problemy teorii ta praktyky: Zb. nauk. pr. Dnipropetrovskoho natsionalnoho un-tu. Dnipropetrovsk: DNU, Vyp. 121, 161-166.

7. Khotomlianskyi A.V. (2004). Amortyzatsiinyi fond yak dzherelo vidtvorennia osnovnykh zasobiv. Ekonomika Ukrainy, № 3, 33-38.

8. Polozhennia (standart) bukhhalterskoho obliku №7 «Osnovni zasoby», zatverdzhene nakazom Ministerstva finansiv Ukrainy vid 18.10.1999 r. № 242, zi zminamy y dopovnenniamy.

9. Podatkovyi kodeks Ukrainy vid 03.12.2010 r. zi zminamy y dopovnenniamy.

10. Derzhavnyi komitet statystyky Ukrainy [Elektronnyi resurs]. Rezhym dostupu : http://www.ukrstat.gov.ua. 